\title{
Effects of exosome-like vesicles on cumulus expansion in pigs in vitro
}

\author{
Yuta MATSUNO ${ }^{1)}$, Asuka ONUMA ${ }^{1}$, Yoshie A FUJIOKA ${ }^{1}$, Kazuma YASUHARA $^{2}$, \\ Wataru FUJII'), Kunihiko NAITO'1) and Koji SUGIURA ${ }^{1)}$ \\ 1) Laboratory of Applied Genetics, Department of Animal Resource Sciences, Graduate School of Agriculture and \\ Life Sciences, The University of Tokyo, Tokyo 113-8657, Japan \\ 2) Biomimetic Materials Science Laboratory, Graduate School of Materials Science, Nara Institute of Science and \\ Technology (NAIST), Nara 630-0192, Japan
}

\begin{abstract}
Cell-secreted vesicles, such as exosomes, have recently been recognized as mediators of cell communication. A recent study in cattle showed the involvement of exosome-like vesicles in the control of cumulus expansion, a prerequisite process for normal ovulation; however, whether this is the case in other mammalian species is not known. Therefore, this study aimed to examine the presence of exosome-like vesicles in ovarian follicles and their effects on cumulus expansion in vitro in pigs. The presence of exosome-like vesicles in porcine follicular fluid (pFF) was confirmed by transmission electron microscopic observation, the detection of marker proteins, and RNA profiles specific to exosomes. Fluorescently labeled exosome-like vesicles isolated from pFF were incorporated into both cumulus and mural granulosa cells in vitro. Exosomelike vesicles were not capable of inducing cumulus expansion to a degree comparable to that induced by follicle-stimulating hormone (FSH). Moreover, exosome-like vesicles had no significant effects on the expression levels of transcripts required for the normal expansion process (HAS2, TNFAIP6, and PTGS2). Interestingly, FSH-induced expression of HAS2 and TNFAIP6 mRNA, but not of PTGS2 mRNA, was significantly increased by the presence of exosome-like vesicles; however, the degree of FSH-induced expansion was not affected. In addition, porcine exosome-like vesicles had no significant effects on the expansion of mouse cumulus-oocyte complexes. Collectively, the present results suggest that exosome-like vesicles are present in pFF, but they are not efficient in inducing cumulus expansion in pigs.
\end{abstract}

Key words: Extracellular vesicles, Granulosa cells, Ovarian follicles, Porcine follicular fluid

(J. Reprod. Dev. 63: 51-58, 2017)

E xtracellular vesicles, such as exosomes, have recently been recognized as mediators of cell communication $[1,2]$. Exosomes are lipid bilayer vesicles with a diameter of about $40-100 \mathrm{~nm}$, and they are released into the extracellular environment by the fusion of multivesicular bodies with the plasma membrane [3-5]. The secretion of exosomes was initially considered as a way for cells to excrete their waste molecules [6]; however, it has recently been shown that exosomes contain mRNAs and micro RNAs (miRNAs), and that these exosome-transported molecules could be translated into proteins or affect translation in target cells [7, 8]. Therefore, exosomes are now considered mediators of cell communication.

The presence and functions of extracellular vesicles, including exosome-like vesicles, have been reported in the ovarian follicular fluid of several mammalian species [9-11]. In horses, follicular exosome-like vesicles affect the expression levels of transcripts related to transforming growth factor- $\beta$ (TGF- $\beta$ )/bone morphogenetic protein (BMP) signaling in mural granulosa cells (MGCs) $[12,13]$. Exosome-like vesicles in human follicular fluid contain miRNAs

Received: August 17, 2016

Accepted: September 30, 2016

Published online in J-STAGE: February 5, 2017

C2017 by the Society for Reproduction and Development

Correspondence: K Sugiura (e-mail: aks@mail.ecc.u-tokyo.ac.jp)

This is an open-access article distributed under the terms of the Creative Commons Attribution Non-Commercial No Derivatives (by-nc-nd) License $<\mathrm{http} / / /$ creativecommons.org/licenses/by-nc-nd/4.0/>. that may regulate biological pathways critical for follicular growth and oocyte maturation [11]. Moreover, exosome-like vesicles in bovine follicular fluid can support the expansion of cumulus cells, at least in vitro [14]. Therefore, exosome-like vesicles in ovarian follicles seem to be regulators of ovarian function by targeting at least granulosa cells $[15,16]$.

Cumulus expansion, also known as cumulus mucification, is a process required for normal ovulation [17]. In vivo, cumulus expansion is triggered by a luteinizing hormone (LH) surge, the intrafollicular signals of which are mediated by the signal of epidermal growth factor (EGF)-like peptides produced by MGCs [18, 19]. Cumulus expansion could be experimentally induced in cumulus-oocyte complexes (COCs) in vitro by stimulating with EGF or follicle-stimulating hormone (FSH) [20,21]. Deficiency in cumulus expansion results in a reduced ovulation rate and subsequent female infertility. Therefore, cumulus expansion is a critical event for maintaining the normal fertility of females.

As mentioned above, exosome-like vesicles isolated from bovine follicular fluid are capable of promoting the expansion of COCs in vitro [14]. This suggests the presence of a novel mechanism regulating cumulus expansion and hence the possible involvement of exosome-like vesicles in the maintenance of female fertility in this species; however, whether this is the case in other mammalian species is not known.

In the present study, we aimed to investigate whether follicular exosome-like vesicles are capable of inducing cumulus expansion 
in pigs. Since the presence of exosome-like vesicles has never been assessed in ovarian follicles of pigs, we first confirmed the presence of exosome-like vesicles in porcine follicular fluid (pFF). Next, we assessed the effects of exosome-like vesicles isolated from $\mathrm{pFF}$ on cumulus expansion of COCs in vitro.

\section{Materials and Methods}

\section{Collection of pFF and cells}

Porcine ovaries of prepubertal gilts were collected at a commercial slaughterhouse (Tokyo Shibaura Zouki, Tokyo, Japan) and transported to our laboratory at approximately $37^{\circ} \mathrm{C}$ in saline. pFF was collected from antral follicles 2-5 $\mathrm{mm}$ in diameter as previously reported [22].

Porcine COCs and MGCs were collected from antral follicles $2-5 \mathrm{~mm}$ in diameter as previously reported [23-25].

\section{Isolation of exosome-like vesicles from $p F F$}

Before exosome-like vesicle isolation was carried out, $\mathrm{pFF}$ was centrifuged at $2,000 \times \mathrm{g}$ at $4^{\circ} \mathrm{C}$ for $30 \mathrm{~min}$ and then at $12,000 \times \mathrm{g}$ at $4^{\circ} \mathrm{C}$ for $45 \mathrm{~min}$, followed by filtration through a $0.22-\mu \mathrm{m}$ membrane (Merck Millipore, Darmstadt, Germany) to remove cells and debris. After the filtration, the $\mathrm{pFF}$ samples were stored at $-80^{\circ} \mathrm{C}$ until they were processed for further analysis. A fraction that potentially contained exosomes (hereafter, "exosomal fraction") was isolated from the filtered pFF samples using a Total Exosome Isolation (from serum) reagent (Life Technologies, Carlsbad, CA, USA) and centrifugation according to the manufacturer's protocol. For culture experiments, isolated exosomal fractions were resuspended in a volume of culture medium that was double of the original volume of $\mathrm{pFF}$, and immediately used for cultures (described below).

\section{Transmission electron microscopy (TEM) observations of the exosomal fraction}

The exosomal fraction isolated from $\mathrm{pFF}$ was resuspended in $\mathrm{NaHCa}$ buffer (30 mM HEPES, $100 \mathrm{mM} \mathrm{NaCl}, 2 \mathrm{mM} \mathrm{CaCl}_{2}, \mathrm{pH}$ 7.4). The resuspended exosomal fraction was applied on a 200-mesh copper microgrid covered with a formvar support film, which had been pre-treated with soft plasma etching equipment (SEDE-AF, Meiwafosis, Tokyo, Japan) to obtain a hydrophilic surface. The microgrid was electron-stained with $1 \%$ uranium acetate solution for $10 \mathrm{~min}$ and then with lead acetate solution for $10 \mathrm{~min}$. Finally, the microgrid was observed with a transmission electron microscope (JEM-1010; JEOL, Tokyo, Japan).

For cryogenic TEM (Cryo-TEM), the resuspended exosomal fraction in NaHCa buffer was applied on a 200-mesh copper microgrid that had been pre-treated with a glow-discharger (HDT-400, JEOL) to obtain a hydrophilic surface. The microgrid was immediately plunged into liquid propane using a specimen preparation machine (EM CPC; Leica) and then transferred to a cryo-transfer holder (Model 626-DH; Gatan, Pleasanton, CA, USA). Finally, the microgrid was observed with a transmission electron microscope (JEM-3100FEF; JEOL) at an acceleration voltage of $300 \mathrm{kV}$ in zero-loss imaging mode. The temperature of the microgrid was maintained below $-140^{\circ} \mathrm{C}$ during the observation.

\section{Western blot analysis}

Proteins were isolated from the exosomal fraction and MGCs using TRIZOL Reagent (Life Technologies) according to the manufacturer's protocol, and were resuspended in $8 \mathrm{M}$ urea buffer $(8 \mathrm{M}$ urea, 10 $\mathrm{mM}$ dithiothreitol, $50 \mathrm{mM}$ Tris(hydroxymethyl)aminomethane, $\mathrm{pH}$ 8.0). Laemmli buffer [26] was added to each sample and immediately boiled for $5 \mathrm{~min}$. Western blot analysis was conducted as previously reported [27]. The primary antibodies used were anti-HSC70 antibody (MAB2191; Abnova, Taipei, Taiwan), antiACTB antibody (GTX109639; GeneTex, CA, USA), and anti-CYCS antibody (sc-13156; Santa Cruz Biotechnology, Texas, USA), and the secondary antibodies used were horseradish peroxidase conjugated anti-rabbit IgG (AP132P; Merck Millipore), anti-rat IgG (81-9520; Invitrogen), and anti-mouse IgG antibodies (115-035-044; Jackson ImmunoResearch, West Grove, PA, USA). Signals were visualized using an Immunostar LD Kit (Wako, Tokyo, Japan) and the C-DiGit Blot Scanner and Image Studio for C-DiGit (LI-COR, Lincoln, NE, USA) according to the manufacturer's protocols.

\section{RNA profiling using a bioanalyzer}

Total RNA was extracted using the miRCURY ${ }^{\mathrm{TM}}$ RNA Isolation Kit - Cell \& Plant (Exiqon, Vedbæk, Denmark) according to the manufacturer's protocol. The concentration of isolated total RNA was determined using a NanoDrop Lite spectrophotometer (Thermo Scientific, Hudson, NH, USA). The total RNA profiles were visualized by using an Agilent 2100 bioanalyzer (Agilent Technologies, Palo Alto, CA, USA) and Agilent RNA6000 Pico Kit (Agilent Technologies). In addition, the miRNA (10-40 nt) concentrations were analyzed by using an Agilent 2100 bioanalyzer (Agilent Technologies) and Agilent Small RNA Kit (Agilent Technologies) according to the manufacturer's protocols.

\section{Assessing the incorporation of exosome-like vesicles into} MGCs or COCs

To assess the incorporation of follicular exosome-like vesicles into cells, the exosomal fraction isolated from pFF was labeled with green florescent PKH67 dye (Sigma-Aldrich, St. Louis, MO, USA) and washed with successive centrifugations according to the manufacturer's protocol. PKH67 dye without the exosomal fraction was subjected to the same procedure for the negative control treatment. Minimum essential medium alpha (MEM $\alpha$ ) (Life Technologies) supplemented with $75 \mu \mathrm{g} / \mathrm{ml}$ penicillin $\mathrm{G}, 50 \mu \mathrm{g} / \mathrm{ml}$ streptomycin sulfate, and $3 \mathrm{mg} / \mathrm{ml}$ bovine serum albumin (BSA; Sigma-Aldrich) was used as the culture medium for MGCs. Modified North Carolina State University-37 medium (mNCSU-37) was used as the culture medium for porcine COCs. All the cultures were maintained at $38^{\circ} \mathrm{C}$ and $5 \% \mathrm{CO}_{2}$ in air.

MGCs were re-suspended in the MGC-culture medium supplemented with $5 \%$ fetal bovine serum (FBS), and $2.0 \times 10^{5}$ viable cells were plated on $18 \times 18 \mathrm{~mm}$ cell culture cover glasses (Matsunami Glass Ind, Osaka, Japan) placed in a 35-mm dish (100-035; Iwaki, Chiba, Japan). Then, MGCs were cultured for $24 \mathrm{~h}$ to induce attachment to the cover glasses. After the culture, the medium was exchanged for the MGC culture medium containing the PKH67-labeled exosomal fraction, and the MGCs were cultured for an additional $24 \mathrm{~h}$. To assess the incorporation of follicular exosome-like vesicles into COCs, 
COCs were placed in 1 well of a 4-well plate (SPL Life Sciences, Seoul, Korea) in a COC-culture medium supplemented with 10 IU/ $\mathrm{ml}$ equine chorionic gonadotropin (eCG) (ASKA Pharmaceutical, Tokyo, Japan), $10 \mathrm{IU} / \mathrm{ml}$ human chorionic gonadotropin (ASKA Pharmaceutical), $1 \mathrm{mM} N^{6}, 2^{\prime}$-O-dibutyryladenosine $3^{\prime}, 5^{\prime}$-cyclic monophosphate sodium salt (Sigma-Aldrich), and the PKH67-labeled exosomal fraction, and cultured for $24 \mathrm{~h}$.

After the culturing with the PKH67-labeled exosomal fraction, cells were washed twice in PBS, fixed with paraformaldehyde (16320145; Wako, Osaka, Japan), and subsequently, treated with $10 \mu \mathrm{g} / \mathrm{ml}$ ribonuclease (DNase free) glycerol solution (312-01931; Wako), and $0.1 \%$ Triton X-100 (Wako). Cells were counterstained with propidium iodide (PI) (PK-CA707-40016; PromoCell, Heidelberg, Germany) for MGCs and with 4',6-diamidino-2-phenylindole (DAPI) for COCs, and then mounted using Permount mounting medium (SP15-100; Fisher Scientific, Pittsburgh, PA, USA). Observations were performed using a laser scanning confocal microscope (LSM700; Carl Zeiss, Oberkochen, Germany) and imaged with LSM-700 ZEN software (Carl Zeiss). A z-stack image was generated by collecting a series of images at 5.02- $\mu \mathrm{m}$ intervals. The negative control experiment gave no signal.

\section{Induction of cumulus expansion by porcine or mouse COCs in vitro}

To assess the effects of follicular exosome-like vesicles on the expression levels of the expansion-related transcripts in porcine COCs in vitro, porcine COCs were cultured in mNCSU-37 medium with or without supplementation of $100 \mathrm{ng} / \mathrm{ml} \mathrm{FSH}$ and/or the exosomal fraction and cultured for $6 \mathrm{~h}$. In the experiment assessing the degree of cumulus expansion, $1 \%$ FBS was added to the culture medium, because a serum-derived inter-alpha-trypsin inhibitor is required to stabilize the expansion in vitro [28]. The possibility that FBS may contain some exosome-like vesicles should not affect the results of this study, because $1 \%$ FBS was supplied to both control (without exosome-like vesicles) and experimental (with exosome-like vesicles) groups. The degree of cumulus expansion was assessed after $44 \mathrm{~h}$ of culture.

To assess the effects of follicular exosome-like vesicles on the degree of cumulus expansion by mouse COCs, COCs were collected from the ovaries of 3-week-old (C57/BL6 $6 \times$ DBA/2) F1 female mice (Sankyo Labo Service, Tokyo, Japan) that had been injected with 5 IU of eCG 45-47 h earlier. Then, mouse COCs were cultured in MEM $\alpha$ containing $75 \mu \mathrm{g} / \mathrm{ml}$ penicillin $\mathrm{G}, 50 \mu \mathrm{g} / \mathrm{ml}$ streptomycin sulfate, and $3 \mathrm{mg} / \mathrm{ml} \mathrm{BSA}$ with or without supplementation of 100 $\mathrm{ng} / \mathrm{ml} \mathrm{FSH}, 10 \mathrm{ng} / \mathrm{ml} \mathrm{EGF}$, and/or the exosomal fraction isolated from $\mathrm{pFF}$. The expression levels of the cumulus expansion-related transcripts in COCs were assessed after $6 \mathrm{~h}$ of culture, and the degree of cumulus expansion was assessed after $14 \mathrm{~h}$ of culture. To stabilize the expansion, 1\% FBS was added in the culture medium in the experiment assessing the degree of cumulus expansion [28]. All animal protocols were approved by the Animal Care and Use Committee of the University of Tokyo.

Isolation of total $R N A$, reverse transcription, and quantitative PCR for $m R N A s$

Real-time PCR analysis was conducted as previously reported [25].
Briefly, total RNA was extracted from COCs using a ReliaPrep ${ }^{\mathrm{TM}}$ Cell Miniprep System (Promega) and reverse-transcribed using a ReverTraAce qPCR Master Mix with gDNA Remover (Toyobo, Osaka, Japan) according to the manufacturer's protocols. Real-time PCR reactions were performed using a THUNDERBIRD qPCR Mix (Toyobo) and an ABI Step One Plus real-time PCR system (Applied Biosystems) according to the manufacturer's protocols. The expression levels of mRNAs were normalized to the levels of a house-keeping gene, ribosomal protein L19 (RPL19), by the $2^{-\Delta \Delta \mathrm{Ct}}$ method [29]. To avoid false-positive signals, dissociation-curve analyses were performed at the end of the analyses, and the PCR products were subjected to agarose gel electrophoresis to confirm the single amplification and sizes of the products. The PCR primers were used according to previous reports $[25,30,31]$. The ranges of amplification efficiencies were $92-97 \%$ and $88-90 \%$ for primers used to amplify cDNA from pigs and mice, respectively.

\section{Statistical analysis}

All experiments were repeated at least 3 times. Student's $t$-test was used for paired comparisons. A P-value of $<0.05$ was considered statistically significant.

\section{Results}

\section{Detection of exosome-like vesicles in $\mathrm{pFF}$}

To investigate whether exosome-like vesicles are present in $\mathrm{pFF}$, the exosomal fraction was isolated from $\mathrm{pFF}$ using a commercially available exosome isolation reagent. TEM observation using the negative staining method revealed that vesicles about $100 \mathrm{~nm}$ in diameter were present in the exosomal fraction isolated from $\mathrm{pFF}$ (Fig. 1A and B). Moreover, round-shaped vesicles of about 100 nm diameter were clearly observed by cryo-TEM (Fig. 1C), which enables the in situ visualization of vesicle structure in water [32]. These vesicles observed by TEM and cryo-TEM exhibited structures similar to those of exosomes in porcine breast milk and the follicular fluid of other mammalian species [9, 10, 33].

Several proteins, such as heat shock protein 70 (HSC70) and beta actin (ACTB), have been reported as markers of exosomes, whereas exosomes do not contain mitochondrial proteins such as cytochrome C (CYCS) because of the biogenesis pathway of exosomes [6, 34]. Therefore, we next examined the presence of these exosomal markers (HSC70 and ACTB) and the absence of CYCS (i.e., the absence of contamination of apoptotic bodies or cell debris) in the exosomal fraction isolated from pFF. As shown in Fig. 1D, HSC70 and ACTB were detected in both MGCs and the exosomal fraction; whereas CYCS was detected only in MGCs but not in the exosomal fraction. This result strongly suggests that the exosomal fraction was free from apoptotic bodies or cell debris.

In general, the RNA profiles in exosomes are characterized by the enrichment of small RNAs and absence of ribosomal RNAs $[35,36]$. Therefore, we next compared the profiles of RNA content between MGCs and the exosomal fraction isolated from $\mathrm{pFF}$. Total RNAs were extracted from MGCs or the exosomal fraction, and the RNA profiles were analyzed by a bioanalyzer (Fig. 1E). The RNAs isolated from MGCs exhibited RNA profiles typical of those observed in cells in general, with 2 clear peaks of ribosomal RNAs (18S and 

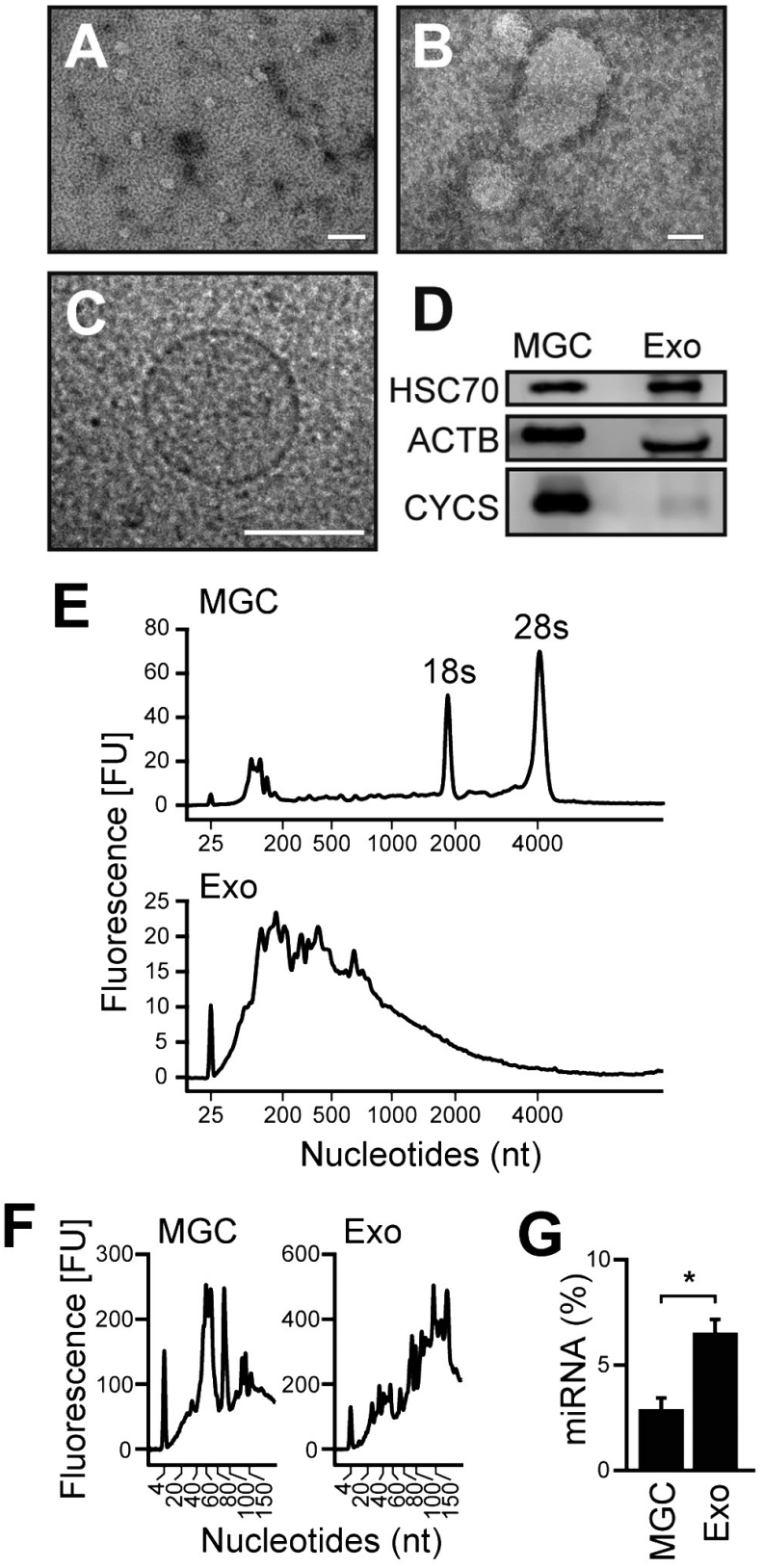

Fig. 1. Detection and characterization of exosome-like vesicles isolated from porcine follicular fluid. (A-C) Representative photographs of vesicles in the exosomal fraction isolated from $\mathrm{pFF}$ observed using TEM with the negative-staining method (A, lower magnification; $\mathrm{B}$, higher magnification) or cryo-TEM (C). The scale bars indicate $200 \mathrm{~nm}$ (A), $50 \mathrm{~nm}$ (B) and $100 \mathrm{~nm}$ (C), respectivelty. (D) Western blotting analysis for HSC70, ACTB, and CYCS. MGC, mural granulosa cells; Exo, exosomal fraction. Profiles of total RNAs isolated from MGCs and the exosomal fraction (Exo) were visualized using a bioanalyzer with either an Agilent RNA6000 Pico Kit (E) or Agilent Small RNA Kit (F), which is designed for profiling smaller RNAs (less than 150 bases). The representative electropherograms show the size distribution in nucleotides (nt) and fluorescence intensity in fluorescence intensity units (FU). (G) Micro RNA contents in total RNAs isolated from MGCs and the exosomal fraction (Exo) on the basis of small RNA profiles shown in (F). Values are shown as the means \pm SEM of independent experiments repeated 3 times. The asterisk denotes a significant difference between the 2 indicated groups $(\mathrm{P}<0.05)$.
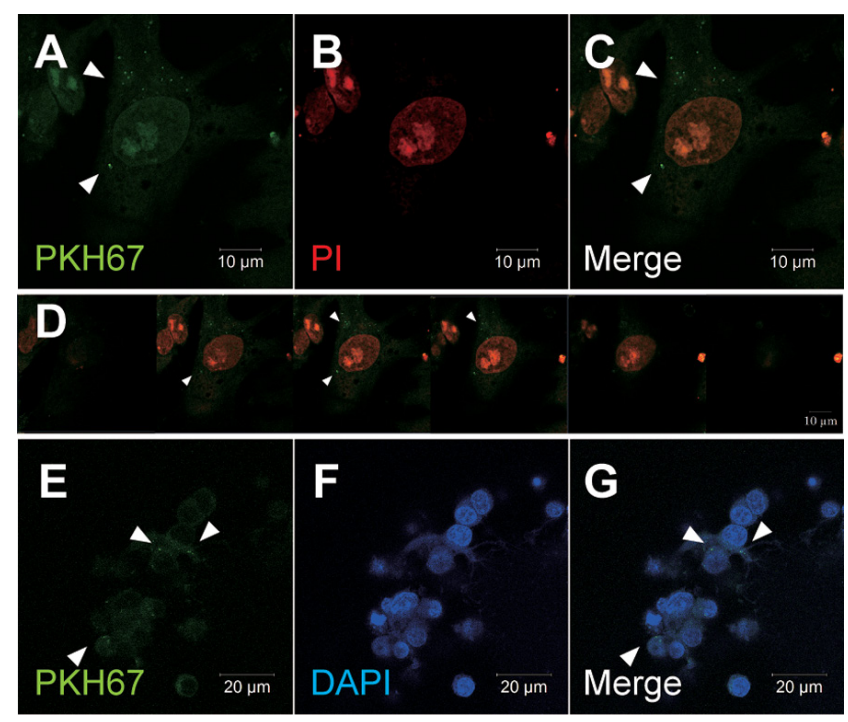

Fig. 2. Incorporation of exosome-like vesicles into MGCs and cumulus cells in vitro. MGCs (A-D) and COCs (E-G) were cultured with PKH67-labeled exosome-like vesicles for $24 \mathrm{~h}$, and observed using a confocal fluorescence microscope. MGCs and COCs were counterstained with PI (B) and DAPI (F), respectively. Bars indicate $10 \mu \mathrm{m}(\mathrm{A}-\mathrm{D})$ and $20 \mu \mathrm{m}(\mathrm{E}-\mathrm{G})$. A z-stack image was generated from the cells shown in A-C by collecting a series of images captured at $0.52-\mu \mathrm{m}$ thickness intervals (D). Arrowheads indicate PKH67-labeled exosome-like vesicles that were taken up by MGCs (A-D) and cumulus cells $(\mathrm{E}-\mathrm{G})$.

28S) [37]. On the other hand, the RNAs isolated from the exosomal fraction were enriched in smaller RNAs, and the peaks of ribosomal RNAs were not observed. Moreover, the miRNA content in RNAs isolated from the exosomal fraction was significantly higher than that in RNAs isolated from MGCs (Fig. 1F and G). These RNA profiles observed in the total RNA isolated from the exosomal fraction were consistent with those of exosomes reported previously [37].

Taken together, these results show that vesicles with the characteristics of exosomes are present in $\mathrm{pFF}$.

\section{Incorporation of exosome-like vesicles into MGCs and} cumulus cells in vitro

To investigate whether exosome-like vesicles isolated from $\mathrm{pFF}$ are incorporated into follicular cells, MGCs and COCs were co-cultured with exosome-like vesicles labeled with green fluorescence dye (PKH67), and the cells were observed by confocal microscopy. As shown in Fig. 2, green fluorescent foci were detected in the cytoplasm of both MGCs (Fig. 2A-D) and cumulus cells (Fig. 2E-G). A $\mathrm{Z}$-stack image showed that the exosome-like vesicles labeled with PKH67 were located within the cytoplasm of the MGCs and thus, they are not simply attached to the cell surface (Fig. 2D). These results showed that exosome-like vesicles labeled with PKH67 were incorporated into MGCs and cumulus cells in vitro. On the other hand, the incorporation of exosome-like vesicles was not observed in oocytes cultured as COCs (not shown). 


\section{A Porcine COCs}

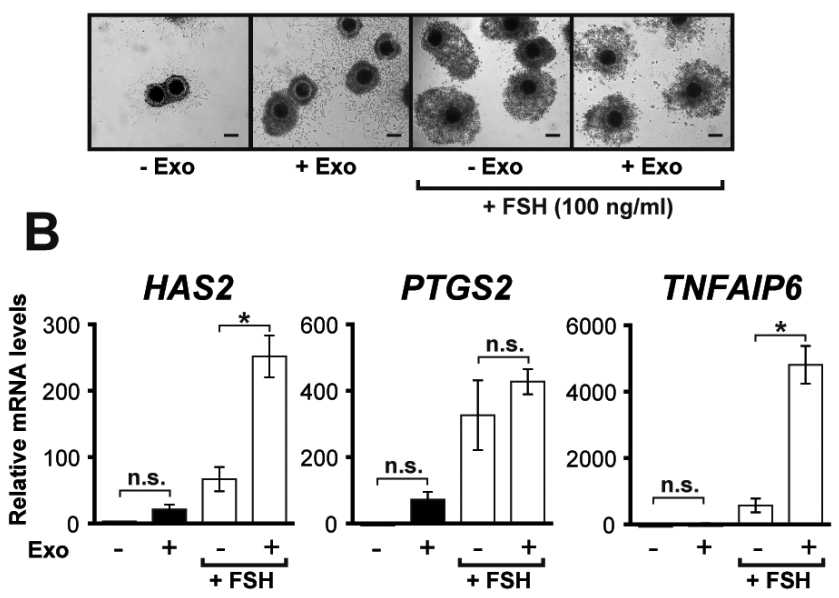

Fig. 3. Effect of exosome-like vesicles on cumulus expansion and expression levels of the cumulus expansion-related transcripts in porcine COCs. (A) Representative photographs of porcine COCs cultured with or without the exosomal fraction (Exo) in the presence or absence of FSH for $44 \mathrm{~h}$. Bar, $100 \mu \mathrm{m}$. (B) Expression levels of the cumulus expansion-related transcripts (HAS2, PTGS2, and TNFAIP6) in COCs cultured for $6 \mathrm{~h}$ with or without the exosomal fraction (Exo) in the presence (white bars) or absence (black bars) of FSH. Values are shown as the means \pm SEM of independent experiments repeated 3 times. The mean values of the expression levels in COCs not treated with the exosomal fraction or FSH were set to 1 . The asterisk denotes significant differences between the indicated groups $(\mathrm{P}<0.05)$. n.s., not significant.

\section{Effect of exosome-like vesicles on the expansion of porcine}

COCs in vitro

Next, we tested whether exosome-like vesicles isolated from $\mathrm{pFF}$ could induce cumulus expansion of COCs in vitro. Porcine COCs were co-cultured with the exosomal fraction isolated from $\mathrm{pFF}$ with or without FSH, and the degree of cumulus expansion was assessed after $44 \mathrm{~h}$ of culture (Fig. 3A). For this experiment, the FSH-induced expansion was used as a positive control of the cumulus expansion as well as expression of the cumulus expansion-related transcripts, because porcine COCs in our experimental model did not respond well to the EGF signal (data not shown), as has also been reported by another group [38].

As shown in Fig. 3A, a slight expansion was observed in COCs cultured with the exosomal fraction for $44 \mathrm{~h}$; however, the degree of expansion was not comparable to the FSH-induced cumulus expansion. Moreover, no difference in the degree of cumulus expansion was observed between COCs treated with FSH alone and those co-treated with both the exosomal fraction and FSH (Fig. 3A).

Several transcripts, such as those encoding hyaluronan synthase 2 (HAS2), prostaglandin-endoperoxide synthase 2 (PTGS2), and tumor necrosis factor alpha-induced protein 6 (TNFAIP6), are known to be required for the normal expansion process [39-43]. Therefore, we next assessed the expression levels of these cumulus expansion-related transcripts in COCs (Fig. 3B).

As shown in Fig. 3B, the expression levels of the cumulus

\section{A Mouse COCs}
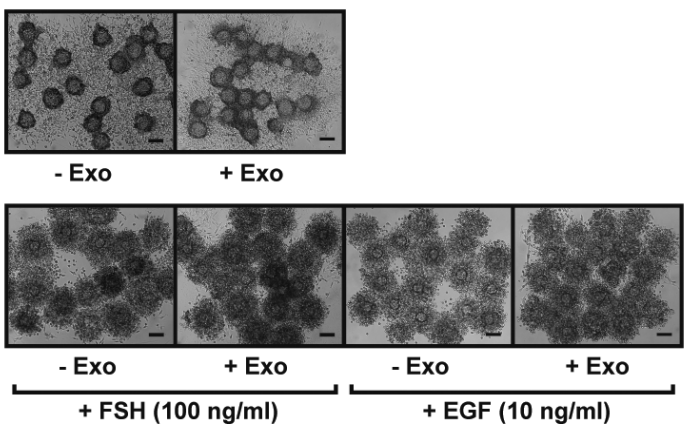

B

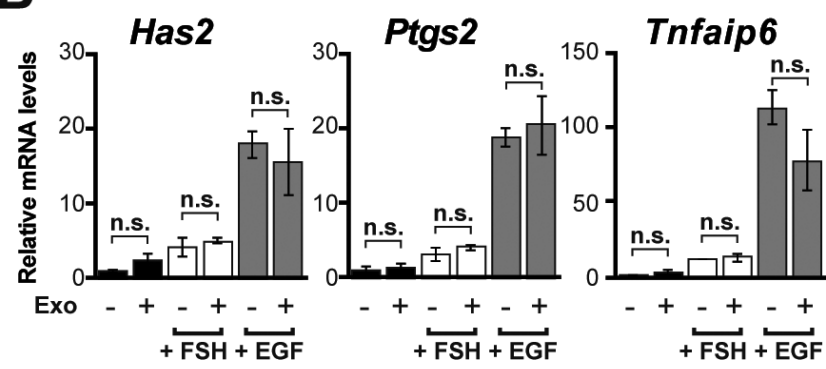

Fig. 4. Effect of exosome-like vesicles on cumulus expansion in mouse COCs. (A) Representative photographs of mouse COCs cultured with or without the exosomal fraction (Exo) in the absence or the presence of FSH or EGF for $14 \mathrm{~h}$. Bar, $100 \mu \mathrm{m}$. (B) Expression levels of the cumulus expansion-related transcripts (Has 2, Ptgs2, and Tnfaip6) in mouse COCs cultured for $6 \mathrm{~h}$ with or without the exosomal fraction (Exo) in the absence (black bars) or presence of FSH (white bars) or EGF (gray bars). Values are shown as the means \pm SEM of independent experiments repeated 3 times. The mean values of the expression levels in COCs not treated with the exosomal fraction, FSH, or EGF were set to 1. n.s., not significant

expansion-related transcripts were not significantly affected by the supplementation of the exosomal fraction. Interestingly, when co-treated with FSH, COCs co-cultured with the exosomal fraction expressed significantly higher levels of HAS2 and TNFAIP6 transcripts compared to those treated with FSH alone. On the other hand, the PTGS2 transcript levels were not affected by the supplementation of the exosomal fraction (Fig. 3B).

Therefore, by themselves, exosome-like vesicles in $\mathrm{pFF}$ are not efficient in promoting the expression of the cumulus expansionrelated transcripts or inducing cumulus expansion by porcine COCs. However, exosome-like vesicles in pFF may have supportive effects on cumulus expression, at least under the present culture conditions.

\section{Effect of exosome-like vesicles of pFF on the expansion of} mouse COCs in vitro

In the previous study in cattle [14], exosome-like vesicles isolated from bovine follicular fluid promoted cumulus expansion by mouse COCs without stimulation with any ligands (i.e., FSH or EGF). Therefore, we next examined whether the exosomal fraction isolated from $\mathrm{pFF}$ is also capable of promoting cumulus expansion by mouse COCs in vitro (Fig. 4).

Supplementation of the exosomal fraction had no effect on 
cumulus expansion in the absence of FSH or EGF (Fig. 4). The FSH or EGF treatment promoted cumulus expansion of mouse COCs, but the degree of the expansion was not affected by co-treatment with the exosomal fraction isolated from pFF (Fig. 4A). Moreover, the expression levels of the cumulus expansion-related transcripts (Has2, Ptgs2, and Tnfaip6) were not significantly affected by the supplementation of the exosomal fraction in mouse COCs with or without FSH/EGF treatments (Fig. 4B). Therefore, porcine follicular exosome-like vesicles are not capable of promoting cumulus expansion of mouse COCs in vitro.

\section{Discussion}

This study demonstrated the presence of exosome-like vesicles in follicular fluid in pigs. Exosome-like vesicles isolated from $\mathrm{pFF}$ were incorporated into both MGCs and cumulus cells in vitro. Moreover, exosome-like vesicles in pFF were found to be inefficient in inducing the expression of cumulus expansion-related transcripts or the expansion of porcine or mouse COCs. Therefore, in contrast to the report in cattle, we found that follicular exosome-like vesicles do not efficiently induce cumulus expansion in pigs.

The results of the present study in pigs showed that exosome-like vesicles in follicular fluid are not efficient in inducing expansion of cumulus cells. However, exosome-like vesicles have been found to efficiently induce cumulus expansion in cattle [14]. Moreover, while bovine exosome-like vesicles are capable of inducing cumulus expansion in mouse COCs [14], exosome-like vesicles in pFF are not. Therefore, the mechanisms regulating cumulus expansion might differ between these mammalian species. Since many differences have already been reported in the mechanism controlling cumulus expansion [44-48], it is possible that the involvement of exosomelike vesicles in cumulus expansion is species-dependent. However, it is important to note that the difference in the methods used to isolate exosome-like vesicles (ultracentrifugation versus isolation reagent) or differences in the culture system may also account for these differences.

Although exosome-like vesicles isolated from $\mathrm{pFF}$ upregulated the expression levels of HAS2 and TNFAIP6 in the presence of FSH, the physiological relevance of this finding needs to be carefully determined, because cumulus expansion in vivo is induced by EGFlike peptides rather than by FSH $[18,19]$. We used FSH-induced expansion as a positive control of cumulus expansion in this study, because the COCs in our experimental model do not respond to EGF signals [38]. Further studies testing the effects of exosome-like vesicles on the cumulus expansion stimulated by EGF/EGF-like peptides in pigs are warranted.

How did exosome-like vesicles isolated from $\mathrm{pFF}$ promote the FSH-induced HAS2 and TNFAIP6 expression in COCs in the present study? It is unlikely that there was any contamination with ligands that could directly activate EGF/FSH signaling in the exosomal fraction, because the exosomal fraction had no effects on cumulus expansion or the expression of related transcripts by mouse COCs. A normal degree of cumulus expansion and expression of the related transcripts requires the activation of mitogen-activated protein kinase 3/1 (MAPK3/1) (also known as extracellular signal-related protein kinase 1/2 (ERK1/2)) [18,49] and SMAD signals [50-53].
Interestingly, there are several reports that exosomes are able to activate these signals in targeted cells. For example, exosomes derived from gastric cancer promote tumor cell proliferation through MAPK/ERK activation [54] and trigger the differentiation of mesenchymal stem cells by activating SMAD signaling [55]. Therefore, it is possible that exosome-like vesicles isolated from $\mathrm{pFF}$ promoted the expression of HAS2 and TNFAIP6 by enhancing these signaling pathways, at least in the present culture system.

The present results showed that the follicular exosome-like vesicles were incorporated not only into cumulus cells but also into MGCs. This indicates that exosome-like vesicles may possess some effects on MGCs as well as cumulus cells in pigs. A previous study in horses suggested that follicular exosome-like vesicles affect the expression levels of transcripts related to TGF- $\beta$ /BMP signaling in MGCs by transferring miRNAs to MGCs $[12,13]$. The present results also identified that small RNAs, including miRNAs, were enriched in the exosomal fraction. In addition, our preliminary study using RNA sequencing identified many miRNAs in the exosomal fraction (not shown). Therefore, a similar mechanism that regulates MGC function through miRNA transfer may exist in porcine follicles. In addition to miRNAs, the enrichment of relatively smaller RNAs $(<2000$ bases) was identified in the exosomal fraction (Fig. 1E). These RNAs may also participate in the regulation of cumulus cell and MGC functions.

The presence of exosome-like vesicles in ovarian follicles has been reported in several mammals, including horses, cows, and humans, but the cellular origin of exosome-like vesicles in follicular fluid has never been determined. Follicular somatic cells (granulosa cells) might be the main source of exosome-like vesicles in follicular fluid. In addition, the oocytes may produce exosome-like vesicles, since exosome-like vesicles exist in the perivitelline space of oocytes [56]. However, exosome-like vesicles secreted from oocytes may not be able to penetrate through the zona pellucida, since we could not detect any oocyte-specific transcripts in our exosomal fraction (not shown). Moreover, since follicular fluid is composed partly of secreted products from follicular cells and partly of transudates of plasma [57], follicular exosome-like vesicles may originate from both intra- and extra-follicular sources. In fact, exosomes secreted from cancer cells can travel via blood flow over large distances and reach other organs [2]. Identifying the origin of follicular exosome-like vesicles will be a critical next step for understanding the roles of exosome-like vesicles in ovarian function and female fertility.

\section{Acknowledgments}

The authors are grateful to Drs Kenji Tomita (The University of Tokyo) and Sakiko Fujita (NAIST) for their technical assistance with the TEM and cryo-TEM observations. We are grateful to Drs John J Eppig (The Jackson Laboratory), Chihiro Emori (The Jackson Laboratory), and Mizuki Ueno (The University of Tokyo) for their helpful input and critical reading of the manuscript. This work was supported by a Grant-in-Aid for Exploratory Research from the Japan Society for the Promotion of Science (No. $16 \mathrm{~K} 15052$ to KS) and a Grant-in-Aid for Trial Use of the Nanotechnology Platform from the National Institute for Materials Science (No. NPS15056 to YM). 


\section{References}

1. Zhang L, Zhang S, Yao J, Lowery FJ, Zhang Q, Huang WC, Li P, Li M, Wang X, Zhang C, Wang H, Ellis K, Cheerathodi M, McCarty JH, Palmieri D, Saunus J, Lakhani S, Huang S, Sahin AA, Aldape KD, Steeg PS, Yu D. Microenvironmentinduced PTEN loss by exosomal microRNA primes brain metastasis outgrowth. Nature 2015; 527: 100-104. [Medline] [CrossRef]

2. Hoshino A, Costa-Silva B, Shen TL, Rodrigues G, Hashimoto A, Tesic Mark M, Molina H, Kohsaka S, Di Giannatale A, Ceder S, Singh S, Williams C, Soplop N, Uryu K, Pharmer L, King T, Bojmar L, Davies AE, Ararso Y, Zhang T, Zhang H, Hernandez J, Weiss JM, Dumont-Cole VD, Kramer K, Wexler LH, Narendran A, Schwartz GK, Healey JH, Sandstrom P, Labori KJ, Kure EH, Grandgenett PM, Hollingsworth MA, de Sousa M, Kaur S, Jain M, Mallya K, Batra SK, Jarnagin WR, Brady MS, Fodstad O, Muller V, Pantel K, Minn AJ, Bissell MJ, Garcia BA, Kang Y, Rajasekhar VK, Ghajar CM, Matei I, Peinado H, Bromberg J, Lyden D. Tumour exosome integrins determine organotropic metastasis. Nature 2015; 527: 329-335. [Medline] [CrossRef]

3. Harding C, Heuser J, Stahl P. Endocytosis and intracellular processing of transferrin and colloidal gold-transferrin in rat reticulocytes: demonstration of a pathway for receptor shedding. Eur J Cell Biol 1984; 35: 256-263. [Medline]

4. Pan BT, Teng K, Wu C, Adam M, Johnstone RM. Electron microscopic evidence for externalization of the transferrin receptor in vesicular form in sheep reticulocytes. $J$ Cell Biol 1985; 101: 942-948. [Medline] [CrossRef]

5. Johnstone RM, Adam M, Hammond JR, Orr L, Turbide C. Vesicle formation during reticulocyte maturation. Association of plasma membrane activities with released vesicles (exosomes). J Biol Chem 1987; 262: 9412-9420. [Medline]

6. Pan BT, Johnstone RM. Fate of the transferrin receptor during maturation of sheep reticulocytes in vitro: selective externalization of the receptor. Cell 1983; 33: 967-978. [Medline] [CrossRef]

7. Valadi H, Ekström K, Bossios A, Sjöstrand M, Lee JJ, Lötvall JO. Exosome-mediated transfer of mRNAs and microRNAs is a novel mechanism of genetic exchange between cells. Nat Cell Biol 2007; 9: 654-659. [Medline] [CrossRef]

8. Kosaka N, Iguchi H, Yoshioka Y, Takeshita F, Matsuki Y, Ochiya T. Secretory mechanisms and intercellular transfer of microRNAs in living cells. J Biol Chem 2010; 285 : 17442-17452. [Medline] [CrossRef]

9. da Silveira JC, Veeramachaneni DN, Winger QA, Carnevale EM, Bouma GJ. Cell-secreted vesicles in equine ovarian follicular fluid contain miRNAs and proteins: a possible new form of cell communication within the ovarian follicle. Biol Reprod 2012; 86: 71. [Medline] [CrossRef]

10. Sohel MM, Hoelker M, Noferesti SS, Salilew-Wondim D, Tholen E, Looft C, Rings F, Uddin MJ, Spencer TE, Schellander K, Tesfaye D. Exosomal and non-exosomal transport of extra-cellular microRNAs in follicular fluid: implications for bovine oocyte developmental competence. PLoS ONE 2013; 8: e78505. [Medline] [CrossRef]

11. Santonocito M, Vento M, Guglielmino MR, Battaglia R, Wahlgren J, Ragusa M, Barbagallo D, Borzì P, Rizzari S, Maugeri M, Scollo P, Tatone C, Valadi H, Purrello M, Di Pietro C. Molecular characterization of exosomes and their microRNA cargo in human follicular fluid: bioinformatic analysis reveals that exosomal microRNAs control pathways involved in follicular maturation. Fertil Steril 2014; 102: 1751-1761.e1. [Medline] [CrossRef]

12. da Silveira JC, Carnevale EM, Winger QA, Bouma GJ. Regulation of ACVR1 and ID2 by cell-secreted exosomes during follicle maturation in the mare. Reprod Biol Endocrinol 2014; 12: 44. [Medline] [CrossRef]

13. da Silveira JC, Winger QA, Bouma GJ, Carnevale EM. Effects of age on follicular fluid exosomal microRNAs and granulosa cell transforming growth factor- $\beta$ signalling during follicle development in the mare. Reprod Fertil Dev 2015; 27: 897-905. [Medline] [CrossRef]

14. Hung WT, Hong X, Christenson LK, McGinnis LK. Extracellular vesicles from bovine follicular fluid support cumulus expansion. Biol Reprod 2015; 93: 117. [Medline] [CrossRef]

15. da Silveira JC, de Andrade GM, Nogueira MF, Meirelles FV, Perecin F. Involvement of miRNAs and cell-secreted vesicles in mammalian ovarian antral follicle development. Reprod Sci 2015; 22: 1474-1483. [Medline] [CrossRef]

16. Machtinger R, Laurent LC, Baccarelli AA. Extracellular vesicles: roles in gamete maturation, fertilization and embryo implantation. Hum Reprod Update 2016; 22: 182-193. [Medline]

17. Chen L, Russell PT, Larsen WJ. Functional significance of cumulus expansion in the mouse: roles for the preovulatory synthesis of hyaluronic acid within the cumulus mass. Mol Reprod Dev 1993; 34: 87-93. [Medline] [CrossRef]

18. Park JY, Su YQ, Ariga M, Law E, Jin SL, Conti M. EGF-like growth factors as mediators of LH action in the ovulatory follicle. Science 2004; 303: 682-684. [Medline] [CrossRef]

19. Shimada M, Hernandez-Gonzalez I, Gonzalez-Robayna I, Richards JS. Paracrine and autocrine regulation of epidermal growth factor-like factors in cumulus oocyte complexes and granulosa cells: key roles for prostaglandin synthase 2 and progesterone receptor. $\mathrm{Mol}$ Endocrinol 2006; 20: 1352-1365. [Medline] [CrossRef]

20. Nagyova E, Camaioni A, Scsukova S, Mlynarcikova A, Prochazka R, Nemcova L, Salustri A. Activation of cumulus cell SMAD2/3 and epidermal growth factor receptor pathways are involved in porcine oocyte-cumulus cell expansion and steroidogenesis. $\mathrm{Mol}$ Reprod Dev 2011; 78: 391-402. [Medline] [CrossRef]

21. Prochazka R, Kalab P, Nagyova E. Epidermal growth factor-receptor tyrosine kinase activity regulates expansion of porcine oocyte-cumulus cell complexes in vitro. Biol Reprod 2003; 68: 797-803. [Medline] [CrossRef]

22. Naito K, Fukuda Y, Toyoda Y. Effects of porcine follicular fluid on male pronucleus formation in porcine oocytes matured in vitro. Gamete Res 1988; 21: 289-295. [Medline] [CrossRef]

23. Fujii W, Nishimura T, Kano K, Sugiura K, Naito K. CDK7 and CCNH are components of CDK-activating kinase and are required for meiotic progression of pig oocytes. Biol Reprod 2011; 85: 1124-1132. [Medline] [CrossRef]

24. Nishimura T, Fujii W, Sugiura K, Naito K. Cytoplasmic anchoring of cAMP-dependent protein kinase (PKA) by A-kinase anchor proteins (AKAPs) is required for meiotic arrest of porcine full-grown and growing oocytes. Biol Reprod 2014; 90: 58. [Medline] [CrossRef]

25. Matsuno Y, Onuma A, Fujioka YA, Emori C, Fujii W, Naito K, Sugiura K. Effects of porcine oocytes on the expression levels of transcripts encoding glycolytic enzymes in granulosa cells. Anim Sci J 2016; 87: 1114-1121. [Medline] [CrossRef]

26. Laemmli UK. Cleavage of structural proteins during the assembly of the head of bacteriophage T4. Nature 1970; 227: 680-685. [Medline] [CrossRef]

27. Sumitomo J, Emori C, Matsuno Y, Ueno M, Kawasaki K, Endo TA, Shiroguchi K, Fujii W, Naito K, Sugiura K. Mouse oocytes suppress miR-3225p expression in ovarian granulosa cells. J Reprod Dev 2016; 62: 393-399. [Medline] [CrossRef]

28. Chen L, Mao SJ, Larsen WJ. Identification of a factor in fetal bovine serum that stabilizes the cumulus extracellular matrix. A role for a member of the inter-alpha-trypsin inhibitor family. J Biol Chem 1992; 267: 12380-12386. [Medline]

29. Livak KJ, Schmittgen TD. Analysis of relative gene expression data using real-time quantitative PCR and the 2(-Delta Delta C(T)) Method. Methods 2001; 25: 402-408. [Medline] [CrossRef]

30. Gilchrist RB, Ritter LJ. Differences in the participation of TGFB superfamily signalling pathways mediating porcine and murine cumulus cell expansion. Reproduction 2011; 142 647-657. [Medline] [CrossRef]

31. Diaz FJ, OBrien MJ, Wigglesworth K, Eppig JJ. The preantral granulosa cell to cumulus cell transition in the mouse ovary: development of competence to undergo expansion. Dev Biol 2006; 299: 91-104. [Medline] [CrossRef]

32. Kikuchi J, Yasuhara K. Microscopy \& micro/nano imaging techniques: TEM. In: Steed J, Gale P (eds.), Supramolecular Chemistry: From Molecules to Nanomaterials. 2012: 633-645.

33. Gu Y, Li M, Wang T, Liang Y, Zhong Z, Wang X, Zhou Q, Chen L, Lang Q, He Z, Chen X, Gong J, Gao X, Li X, Lv X. Lactation-related microRNA expression profiles of porcine breast milk exosomes. PLoS ONE 2012; 7: e43691. [Medline] [CrossRef]

34. Harding C, Heuser J, Stahl P. Receptor-mediated endocytosis of transferrin and recycling of the transferrin receptor in rat reticulocytes. J Cell Biol 1983; 97: 329-339. [Medline] [CrossRef]

35. Lässer C, Eldh M, Lötvall J. Isolation and characterization of RNA-containing exosomes. J Vis Exp 2012; 59: e3037. [Medline]

36. Jenjaroenpun P, Kremenska Y, Nair VM, Kremenskoy M, Joseph B, Kurochkin IV. Characterization of RNA in exosomes secreted by human breast cancer cell lines using next-generation sequencing. PeerJ 2013; 1: e201. [Medline] [CrossRef]

37. Crescitelli R, Lässer C, Szabó TG, Kittel A, Eldh M, Dianzani I, Buzás EI, Lötvall J. Distinct RNA profiles in subpopulations of extracellular vesicles: apoptotic bodies, microvesicles and exosomes. J Extracell Vesicles 2013; 2. [Medline] [CrossRef]

38. Procházka R, Srsen V, Nagyová E, Miyano T, Flechon JE. Developmental regulation of effect of epidermal growth factor on porcine oocyte-cumulus cell complexes: nuclear maturation, expansion, and F-actin remodeling. Mol Reprod Dev 2000; 56: 63-73. [Medline] [CrossRef]

39. Fülöp C, Salustri A, Hascall VC. Coding sequence of a hyaluronan synthase homologue expressed during expansion of the mouse cumulus-oocyte complex. Arch Biochem Biophys 1997; 337: 261-266. [Medline] [CrossRef]

40. Fülöp C, Szántó S, Mukhopadhyay D, Bárdos T, Kamath RV, Rugg MS, Day AJ, Salustri A, Hascall VC, Glant TT, Mikecz K. Impaired cumulus mucification and female sterility in tumor necrosis factor-induced protein-6 deficient mice. Development 2003; 130: 2253-2261. [Medline] [CrossRef]

41. Ochsner SA, Russell DL, Day AJ, Breyer RM, Richards JS. Decreased expression of tumor necrosis factor-alpha-stimulated gene 6 in cumulus cells of the cyclooxygenase-2 and EP2 null mice. Endocrinology 2003; 144: 1008-1019. [Medline] [CrossRef]

42. Ochsner SA, Day AJ, Rugg MS, Breyer RM, Gomer RH, Richards JS. Disrupted func- 
tion of tumor necrosis factor-alpha-stimulated gene 6 blocks cumulus cell-oocyte complex expansion. Endocrinology 2003; 144: 4376-4384. [Medline] [CrossRef]

43. Sugiura K, Su YQ, Eppig JJ. Targeted suppression of Has 2 mRNA in mouse cumulus cell-oocyte complexes by adenovirus-mediated short-hairpin RNA expression. Mol Reprod Dev 2009; 76: 537-547. [Medline] [CrossRef]

44. Buccione R, Vanderhyden BC, Caron PJ, Eppig JJ. FSH-induced expansion of the mouse cumulus oophorus in vitro is dependent upon a specific factor(s) secreted by the oocyte. Dev Biol 1990; 138: 16-25. [Medline] [CrossRef]

45. Ralph JH, Telfer EE, Wilmut I. Bovine cumulus cell expansion does not depend on the presence of an oocyte secreted factor. Mol Reprod Dev 1995; 42: 248-253. [Medline] [CrossRef]

46. Procházka R, Nagyová E, Rimkevicová Z, Nagai T, Kikuchi K, Motlík J. Lack of effect of oocytectomy on expansion of the porcine cumulus. J Reprod Fertil 1991; 93: 569-576. [Medline] [CrossRef]

47. Vanderhyden BC. Species differences in the regulation of cumulus expansion by an oocyte-secreted factor(s). J Reprod Fertil 1993; 98: 219-227. [Medline] [CrossRef]

48. Nakayama T, Inoue M, Sato E. Effect of oocytectomy on glycosaminoglycan composition during cumulus expansion of porcine cumulus-oocyte complexes cultured in vitro. Biol Reprod 1996; 55: 1299-1304. [Medline] [CrossRef]

49. Su YQ, Denegre JM, Wigglesworth K, Pendola FL, OBrien MJ, Eppig JJ. Oocytedependent activation of mitogen-activated protein kinase (ERK1/2) in cumulus cells is required for the maturation of the mouse oocyte-cumulus cell complex. Dev Biol 2003; 263: 126-138. [Medline] [CrossRef]

50. Roh JS, Bondestam J, Mazerbourg S, Kaivo-Oja N, Groome N, Ritvos O, Hsueh AJ. Growth differentiation factor-9 stimulates inhibin production and activates Smad2 in cultured rat granulosa cells. Endocrinology 2003; 144: 172-178. [Medline] [CrossRef

51. Su YQ, Wu X, OBrien MJ, Pendola FL, Denegre JN, Matzuk MM, Eppig JJ. Synergistic roles of BMP15 and GDF9 in the development and function of the oocyte-cumulus cell complex in mice: genetic evidence for an oocyte-granulosa cell regulatory loop. $\mathrm{Dev}$ Biol 2004; 276: 64-73. [Medline] [CrossRef]

52. Dragovic RA, Ritter LJ, Schulz SJ, Amato F, Thompson JG, Armstrong DT, Gilchrist RB. Oocyte-secreted factor activation of SMAD 2/3 signaling enables initiation of mouse cumulus cell expansion. Biol Reprod 2007; 76: 848-857. [Medline] [CrossRef]

53. Peng J, Li Q, Wigglesworth K, Rangarajan A, Kattamuri C, Peterson RT, Eppig JJ, Thompson TB, Matzuk MM. Growth differentiation factor 9:bone morphogenetic protein 15 heterodimers are potent regulators of ovarian functions. Proc Natl Acad Sci USA 2013; 110: E776-E785. [Medline] [CrossRef]

54. Qu JL, Qu XJ, Zhao MF, Teng YE, Zhang Y, Hou KZ, Jiang YH, Yang XH, Liu YP. Gastric cancer exosomes promote tumour cell proliferation through PI3K/Akt and MAPK/ ERK activation. Dig Liver Dis 2009; 41: 875-880. [Medline] [CrossRef]

55. Gu J, Qian H, Shen L, Zhang X, Zhu W, Huang L, Yan Y, Mao F, Zhao C, Shi Y, Xu W. Gastric cancer exosomes trigger differentiation of umbilical cord derived mesenchymal stem cells to carcinoma-associated fibroblasts through TGF- $\beta /$ Smad pathway. PLOS ONE 2012; 7: e52465. [Medline] [CrossRef]

56. Ohnami N, Nakamura A, Miyado M, Sato M, Kawano N, Yoshida K, Harada Y, Takezawa Y, Kanai S, Ono C, Takahashi Y, Kimura K, Shida T, Miyado K, Umezawa A. CD81 and CD9 work independently as extracellular components upon fusion of sperm and oocyte. Biol Open 2012; 1: 640-647. [Medline] [CrossRef]

57. Rodgers RJ, Irving-Rodgers HF. Formation of the ovarian follicular antrum and follicular fluid. Biol Reprod 2010; 82: 1021-1029. [Medline] [CrossRef] 